\title{
PRELIMINARY HISTOANATOMICAL STUDY OF SAPRIA HIMALAYANA GRIFF. F. ALBOVINOSA FLOWER BUDS AND ITS INTERSECTION WITH ITS HOST PLANT TETRASTIGMA LAOTICUM GAGNEP.
}

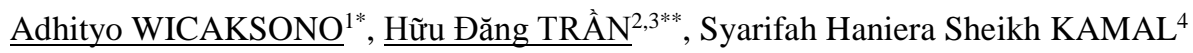

${ }^{1}$ Division of Biotechnology, Genbinesia Foundation, Gresik 61171, East Java - Indonesia.

${ }^{2}$ Southern Institute of Ecology, Vietnam Academy of Science and Technology, Ho Chi Minh City - Vietnam.

${ }^{3}$ Becamex Institute of Research and Development, Becamex IDC Corp., 08, Hung Vuong St., Hoa Phu Ward, Thu Dau Mot City, Binh Duong Province - Vietnam.

${ }^{4}$ Faculty of Applied Sciences, University Teknologi MARA, 40450 Shah Alam, Selangor - Malaysia.

* Corresponding authors. E-mail: adhityo.wicaksono@gmail.com; tranhuudang@gmail.com

\begin{abstract}
Sapria, a holoparasitic plant of Rafflesiaceae is still understudied in term of anatomical, even more in histoanatomical study. This study aimed to perform preliminary observation on Sapria himalayana Griff. f. albovinosa morphology on its early and late stage of flower bud development inside its host, Tetrastigma laoticum Gagnep. (Vitaceae). The results show the progression from the early flower bud as it starts to grow in the host vascular cambium area towards proximal direction to reach the host xylem and distal direction to reach the host phloem and to reach the next stage of the life cycle, into the late flower bud where differentiation occurs. In late flower bud, some primordial of the organs are visible as the flower bud grows larger distally towards the periderm. This development pattern is similar to the progression of development in the previous studies in Rafflesia and Rhizanthes, where endophytic growth was observable in both proximal (xylem area) and distal (peridermal). Future comparative study is encouraged, especially to compare between Sapria species and between different stages of growth. Although, an efficient method and less invasive way of sampling is encouraged to prevent decline of Sapria species in the wild.
\end{abstract}

Keywords: anatomy, flower, holoparasite, parasitic plant, Rafflesiaceae.

\section{Introduction}

Sapria is one of holoparasitic plant in Rafflesiaceae. Its distribution is restricted to the South China, East India, Myanmar, Vietnam, and Thailand region [AHMAD \& al. 2020]. Just like two other genera of Rafflesiaceae, Rafflesia and Rhizanthes, Sapria is also a parasite of Tetrastigma (Vitaceae) liana. So far, Sapria consisted only by four species, Sapria himalayana Griff., S. myanmarensis Nob. Tanaka, Nagam., Tagane \& M. M. Aung, S. poilanei Gagnep., and S. ram Bänziger \& B. Hansen. All grown in specific Tetrastigma species as well, such as $S$. himalayana with T. obovatum (Laws.) Gagnep., T. laoticum Gagnep., and T. cruciatum Craib \& Gagnep. [ELLIOTT, 1992], S. poilanei with T. laoticum, S. ram with T. harmandii Planch. [BÄNZIGER \& HANSEN, 1997]. Only S. myanmarensis has undocumented Tetrastigma species.

Some papers refer Sapria, specifically S. himalayana to also grow in other Vitaceae, Vitis sp. [HUANG \& GILBERT, 2004, cit. WEAVER, 105]. However, since no study has reported which species of Vitis, the speculation remained dubious, especially since some Tetrastigma species were once considered as genus Vitis until Jules Émile Planchon excluded the genus in 1887 [RAHAYU \& al. 2018]. 
Previous anatomical-histological study has been done in Rafflesiaceae. In Rafflesia, the study was by NIKOLOV \& al. (2014a, 2014b), MURSIDAWATI \& al. (2019, 2020), MURSIDAWATI \& WICAKSONO (2020), and KAMAL \& al. (2021). In the same literature by NIKOLOV \& al. (2014a, 2014b), there are also anatomical study on Rhizanthes, and only in few parts on Sapria as endophyte.

Therefore, no study until now has reveal the anatomical development of Sapria. All three genera are known as root parasites of Tetrastigma, but only Raffesia is known for its aerial form grown in the aerial/erected root of Tetrastigma liana, as alternative form to most found terrestrial form [MURSIDAWATI \& al. 2021]. Both Rhizanthes and Sapria until now, only known to grow in terrestrial form.

This preliminary study aim is to reveal the general, semi-microscopic parasitic-host profile of S. himalayana Griff. f. albovinosa on its host $T$. laoticum on the early bud and later bud. This profile will provide first, preliminary information about Sapria and Tetrastigma parasite-host relationship. From this study, in the future, the profile between all Rafflesiaceae genera can be made.

\section{Material and methods}

\section{Plant preparation}

Host tissue is Tetrastigma laoticum Gagnep. infected with S. himalayana Griff. f. albovinosa (Figure 1). The specimen was taken in March 2019 at Lang Biang Plateau, Vietnam, specifically at Tuyền Lâm Lake, Cam Ly and Nam Ban Protection Forest (similar to the sampling area of the previous study, TRÂN \& al. 2018). The plant materials were sent to Ho Chi Minh City Medicine and Pharmacy University, Faculty of Pharmacy for the staining and microscopy sample preparations.

\section{Staining and microscopy analysis}

The staining method applies carmine alum and iodine green, aimed to stain the lignified tissue in green while the rest part of tissue in red [LOCQUIN \& LANGERON, 2013]. The samples were prepared by slicing manually by hand with razor for approximately $200 \mu \mathrm{m}$ thick. Then, the samples were soaked in sodium hipochlorite/commercial bleach ( $\mathrm{NaHClO})$ for 15 minutes or until the samples were completely discolored, and cleansed with tapwater for 4 times to remove the bleach. To initiate the staining, the samples were soaked in acetic acid $10 \%$ for 5 minutes and rinsed, before soaked in carmine alum dye and iodine green for 15 minutes. The samples were then cleansed from the dye in tap water for 2 times and preserved in glycerol $50 \%$ until observation under light microscope. 


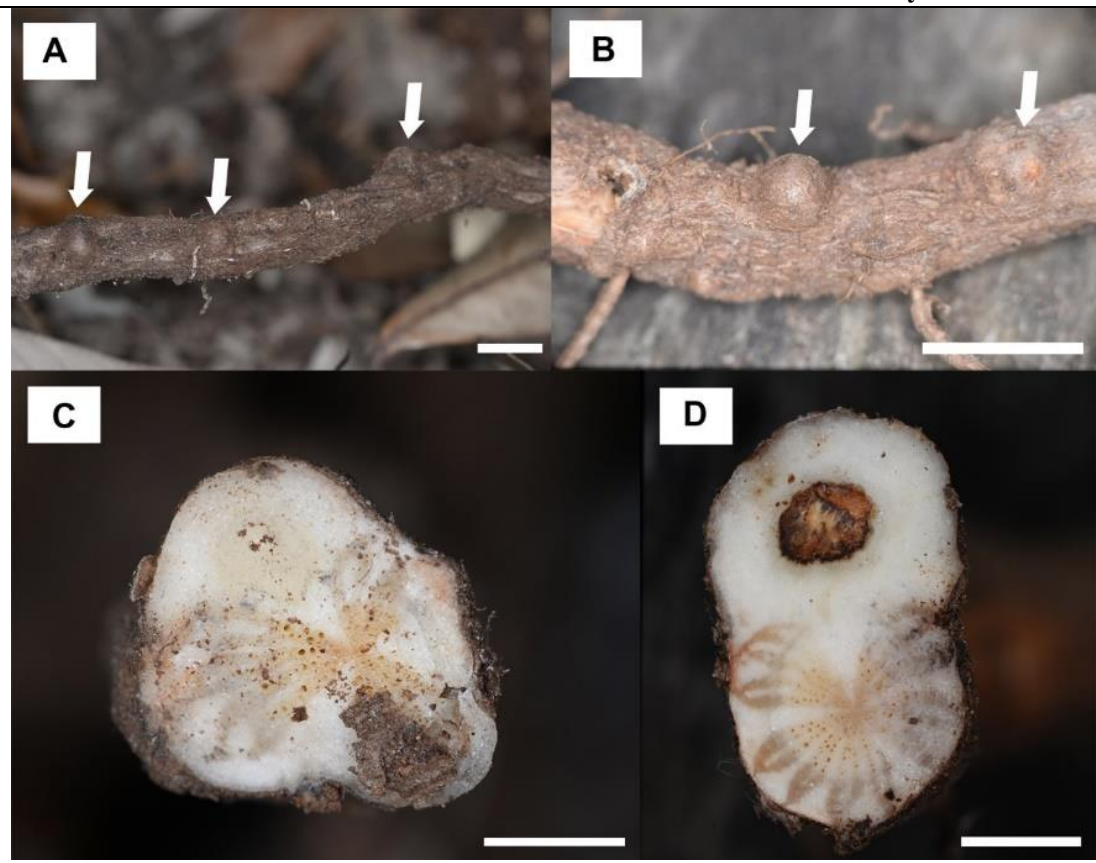

Figure 1. Root of T. laoticum with S. himalayana f. albovinosa buds at swollen stage (white arrows) (A) and zoomed root area with buds (B). Cross-sectioned root with the early stage of bud (C) and late stage (D). Scale bars $=1 \mathrm{~cm}(\mathrm{~A}, \mathrm{~B}), 0.5 \mathrm{~cm}(\mathrm{C}, \mathrm{D})$. Photo by Trần Hữu Đăng.

\section{Results}

\section{Early bud}

At early bud stage (Figure 2), the flower bud (or Sapria parasitic tissue, SPT) morphologically resembles an inverted teardrop figure. The proximal part of the flower bud is located between the host secondary xylem vessels, and the distal part is located between the bent host secondary phloem with the farthest distal tip in contact with the host cortex layer. The neighboring phloem bundles of the host have been disfigured by the flower bud distal area growth as it appears to be laterally flattened (Figure 2; PAP). The neighboring xylem bundles of the host, however, only partially disfigured in the proximity area to the flower bud proximal area (Figure 2; PAX).

As comparison, closer to the T. laoticum root cross-sectional core, the xylem appears to be unchanged as the rest of xylem bundles located farther away from the Sapria flower bud growth. The parasitic tissue non-affected (normal) root vascular bundle of T. laoticum has developed through secondary growth, with ramified secondary xylem area of the vascular bundle (Figure 2; SX) at the proximal point close to the pith (Figure 2; Pi), bordered with vascular cambium (Figure 2; VC) before the phloem, and re-merged in the secondary phloem area of the vascular bundle (Figure 2; SP) close to the cortex layer of the root (Figure 2; Pe/Cx).

The root with secondary growth has its original cortex layer compressed outwards to the epidermis layer, forming a periderm/cork layer, while the new cortex tissue developed from meristematic pericycle tissue along with the vascular cambium [BECK, 2010; GAMBETTA \& 
al. 2013], hence the labeling of cortex in this figure. Although, the thin layer of the periderm is consistent to NIKOLOV \& al. (2014a) study, which found rhytidome in Rafflesia-infected Tetrastigma only, not Sapria and Rhizanthes, where the phellogen is originated from outer cortex cells.

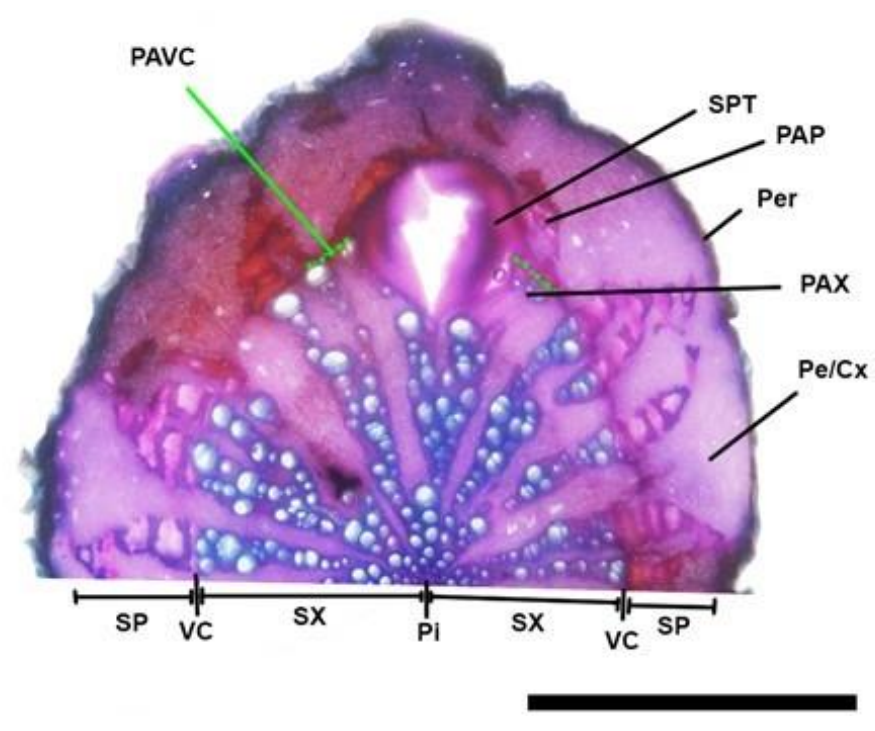

Figure 2. Halved T. laoticum root cross-sectional view with early/pre-cupular S. himalayana f. albovinosa bud (5 month-old), stained with carmine alum-iodine green staining, under light microscope. $\mathrm{Pe} / \mathrm{Cx}-$ Pericyle/Root Cortex, PAX - Parasite-affected xylem, PAP - Parasite-affected phloem, PACV - Parasiteaffected vascular cambium (marked with green dotted lines), Per - Root periderm, SPT - Sapria parasitic tissue, SP - Secondary phloem of host, VC - Host vascular cambium, SX - Secondary xylem of host, Pi Pith (tiny area in the middle of the root cross-section). Scale bar $=0.5 \mathrm{~cm}$. Magnification: $10 \times 10$. Photo by Nguyễn Thị Ngọc Hương, brightness-contrast-saturation was enhanced by Adhityo Wicaksono.

\section{Late bud}

At later stage, the flower bud growth initiates the pre-cupula/swollen stage (analogous to Rafflesia life cycle staging by SUSATYA, 2020), where it exhibits gall-like growth that pushes the cortex and periderm area further outwards, swelling the appearance (hence the stage name). At this stage, the bud emergence is already visible by eyes (see Figure $1 \mathrm{~A}$ and $\mathrm{B}$, white arrows). Despite the flower sex is not yet determined, the possible ovary region (if the flower develops into female or bisexual flower) is already visible in the cross-section (Figure 3; PriOv). The rest of the vegetative structure primordials are also already developed, e.g., primordial central chamber (Figure 3; PriCh) and primordial perigone lobes and bracts (Figure 3; PriPer).

In early development of the late flower bud (Figure 3A), the central chamber already possesses the streaks that is closely resembles the mature flower [TRÀN \& al. 2018], while the perigone-bract primordial remains undifferentiated. In later development of the bud (Figure 3B), central chamber enlarges, other vegetative structures like the central column (Figure 3; PriCC) is now visible, and the primordial perigone-bract layers has formed a protective layer surrounding the central chamber of the flower (and the flower undeveloped diaphragm). These 
additional parts will develop into the flower organ of Sapria. The number of affected host vascular bundles cannot be seen clearly, however the pattern of the parasitic tissue growth shows the similar trend as in the early bud (Figure 2). The parasite-affected tissue (Figure 3; PAT) has pushed the host vascular bundles further laterally and grows deeply into the host secondary xylem area.

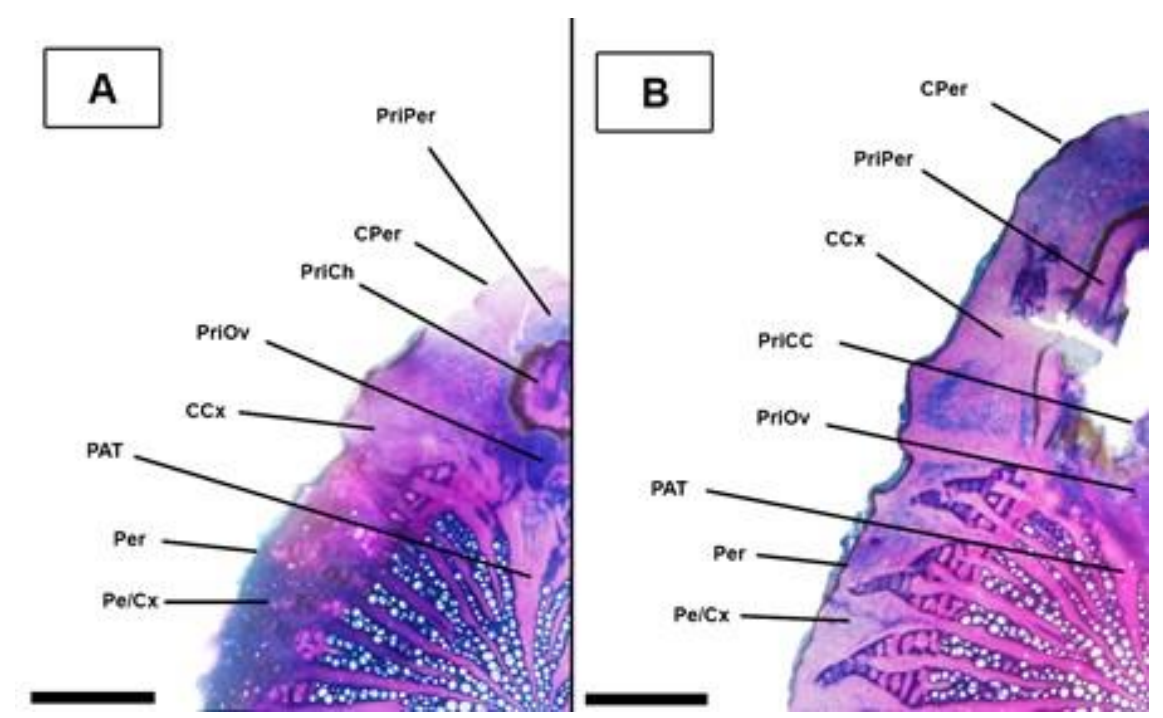

Figure 3. Quarter of T. laoticum root cross-section with S. himalayana f. albovinosa bud in late stage of pre-cupula stage, stained with carmine alum-iodine green staining, under light microscope. At 5 monthold (A) and 7 month-old (B). Pe/Cx - Pericyle/Root Cortex, Per - Root periderm, PAT - Parasite-affected tissue, $\mathrm{CCx}$ - Cupular cortex, PriOv - Primordial ovary (if the flower is female), PriCC - Primordial central column, PriCh - Primordial central chamber, PriPer - Primordial perigone lobes-bracts, CPer Cupular periderm. Scale bars $=0.25 \mathrm{~cm}$. Magnification: $10 \times 10$. Photo by Nguyễn Thị Ngọc Hương, brightness-contrast-saturation was enhanced by Adhityo Wicaksono.

\section{Discussions}

\section{Sapria tissue growth and comparison across Rafflesiaceae}

In general, during swollen stage or pre-cupula stage (analogous to Rafflesia life stage description by SUSATYA \& al. 2020), the parasitic tissue of Sapria appears morphologically like an inverted teardrop. This morphology resembles to the floral development stage in the rest of Rafflesiaceae genera, based on observation in Rafflesia patma Blume [MURSIDAWATI \& WICAKSONO, 2020], R. azlanii Latiff \& M. Wong [KAMAL \& al. 2021], Rhizanthes lowii (Becc.) Harms [NIKOLOV \& al. 2014b]. The parasitic tissue (Figure 2 and 3; PAT) is centered in the vascular cambium tissue layer of the host root. The proximal region of the parasitic tissue appears to grow towards the core of the root where xylem vessels are abundant, presumably to obtain water and minerals from the host xylem, while the distal region starts to grow and swell towards the surface (direction of the root periderm) and reach the host phloem for nutrition.

This type of movement also can be seen in Rafflesia species [MURSIDAWATI \& WICAKSONO, 2020; KAMAL \& al. 2021] and Rhizanthes [NIKOLOV \& al. 2014a] where the 
parasite tissue grows proximally towards the host root xylem area with the conic-shaped tissue in the host-parasitic attachment/haustorial region.

In the early bud stage (Figure 2), the penetration of the parasitic tissue goes between two xylem area of the vascular bundles, altering the growth of the adjacent vascular bundles, while the remaining vascular bundles continues to grow normally. This is consistent to the Rafflesia study in KAMAL \& al. (2021), where the early stage of $R$. azlanii bud with size of 2.7 $\mathrm{cm}$, and $R$. patma in MURSIDAWATI \& WICAKSONO (2020) only penetrated to single area of host vascular bundles. Assumptively, the number of damaged host vascular bundles in Rafflesia-infected Tetrastigma is increased by the age of flower bud growth as the parasitic tissue is growing larger and larger, compressing more vascular tissue of the host [MURSIDAWATI \& WICAKSONO, 2020]. One vascular bundle is damaged during the cupule stage, two vascular bundles in cupule-bract transition (CBT) stage and three host vascular bundles ruptured by Rafflesia in the bract stage for $R$. azlanii and R. cantleyi [KAMAL \& al. 2021]. In the case of multiple bud formation (as in Figure 1A and B; for Rafflesia in MURSIDAWATI \& WICAKSONO, 2020), the multiple buds are most likely to grow in the same orientation. This "behavior" is believed to be a strategy to minimize the damage of the host, preventing the death of the host that will ultimately also killing the parasite [MURSIDAWATI \& WICAKSONO, 2020].

In initial growth, the primordial tissues develop into the primordial ovary area, followed by the chamber, and perigone lobe-bract primordial area (as shown in Figure 2). In later growth, the floral central chamber expands, the central column matured to then develop the anther/stigmatic region in mature flower, and the laminations by perigone lobes and bracts primordial is becoming visible. This growth pattern resembles the Rafflesia at 3-months-old stage, which also considered as early bud growth. The growing meristematic tissue was composed of three regions namely proximal region, middle and distal region, where the proximal region consisted of elongated cells that interference with the host tissues, followed by the middle area, which the location of ovary flower developed at the later stage and distal region where the bracts and perigone lobes developed [MURSIDAWATI \& WICAKSONO, 2020].

\section{Host-parasite intersection pattern across Rafflesiaceae}

Despite the great resemblances across Rafflesiaceae for the stage in floral accessory growth pattern, the host-parasite intersection area or haustorium in all three genera are slightly different. Rafflesia endophyte is distributed in the host vascular cambium area close to the host phloem [NIKOLOV \& al. 2014a; MURSIDAWATI \& al. 2019], Rhizanthes (based on Rh. lowii) is distributed from the host phloem, host vascular cambium, and even between the host xylem vessels [NIKOLOV \& al. 2014a], and for Sapria, the information is still limited as in the study by NIKOLOV \& al. (2014a), Sapria endophyte was found in the vascular cambium layer of the host. The newest update, however, revealing the growth activity of Rafflesia endophyte in the xylem as well [BASCOS \& al. 2021], which is similar to Rhizanthes [NIKOLOV \& al. 2014a]. The reason and mechanisms behind Rafflesiaceae endophytic growth towards the host xylem area require further investigation.

Even in the flower bud stage, the haustorial growth pattern in three genera appears to be distinctive. The proximal meristematic growth in Rafflesia appears to be restricted, as the haustorium intersection is found only in the vascular cambium layer and albeit slightly close to the xylem area [MURSIDAWATI \& al. 2019; KAMAL \& al. 2021].

In Rhizanthes (based on $R h$. lowii), the proximal meristematic growth is visible and the haustorium intersection reaches the xylem bundles area [NIKOLOV \& al. 2014a]. Based on this 
Adhityo WICAKSONO \& al.

study, Sapria appears to exhibit the same pattern with the other Rafflesiaceae member genera. There should be some differences in morphological adaptations of the haustorium, especially since Sapria is the only Rafflesiaceae that infects Vitis, not only Tetrastigma [HUANG \& GILBERT, 2003], although no clarification of which Vitis species infected by Sapria until now. Hypothetically, due to growth in small Tetrastigma root area but possess relatively large (host cross-sectional diameter to the flower size), Rhizanthes and Sapria requires greater anchorage to the host.

Comparatively, Rafflesia is often found in larger root area and even in aerial root with large diameter. As Rafflesia flower size is also massive [NAIS, 2001], shallower haustorium possibly reduces mechanical damage to the host, thus preventing further stress in the host that will potentially kill it, endangering the parasite.

\section{Future prospects}

This study has some limitations, including sample variations and details. More species can be aimed for future sampling, as well as multiple organ sampling during different stage of development or flower organs during blooming/anthesis period. Multiple organ histoanatomical study can be used to understand the different features in the flower or even endophyte inside Tetrastigma in a species or across multiple species. This similar concept of study has been done initially by NANTAWAN \& SUVIT (2002), and later by MURSIDAWATI \& al. (2020) in Rafflesia. Moreover, the haustorial attachment differences between all three genera can also be modelled in biomechanics study.

However, this sampling for histoanatomical analysis, requires strategic and optimized sampling, especially due to the rarity of Sapria (i.e., S. himalayana is considered "Vulnerable", $S$. poilainei and $S$. ram is considered "Endangered" under IUCN Red List; CHAMCHUMROON \& al. 2017). Despite the rest of the species are not considered endangered, Rafflesiaceae, especially based on Rafflesia, has complex yet mysterious life cycle that implies if the number in the wild is reduced, the recovery process will take a long period of time [WICAKSONO \& al. 2020].

Based on this condition, propagation study of Sapria, as in Rafflesia, should be greatly encouraged. Also, potential future studies require efficient sampling method with to optimize the amount of data with only small amount of sample and development of less invasive method of analysis to reduce the chance of population disruption during progression of the study.

\section{Conclusions}

Sapria has not became a subject of anatomical study, compared to other Rafflesiaceae members, Rafflesia and Rhizanthes. This study provides brief preliminary overview on Sapria histoanatomy, using $S$. himalayana f. albovinosa samples, stained using carmine alum-iodine green. The results show the progression of Sapria growth from the young, inverted-teardroplike early flower bud, to the late flower bud that already developed some primordial organs, including flower chamber, central column, and perigone lobe-bract complex.

In term of haustorial intersection, Sapria is similar to all Rafflesiaceae genera, Rhizanthes and Rafflesia, as the proximal growth reaches the xylem area of the host. Although further investigation is required in anatomical samples of all Rafflesiaceae genera in the future to confirm this statement. From the functionality aspect, this deeper anchorage facilitates the large flower growth in small roots, although biomechanical study is required to confirm this hypothesis. Future study to obtain higher details on each organ during different stage of growth 
or across different Sapria species is encouraged with strategic way of sampling and optimized way to obtain the data.

\section{Notes on contributors}

Adhityo WICAKSONO - is a researcher in Generasi Biologi Indonesia (Genbinesia) Foundation as Head of Biotechnology Department in 2018 until now. His main research is on plant science, focused on Rafflesiaceae since 2017 and plant molecular biology. He is also a PhD student in Åbo Akademi University, Finland.

Hữu Đăng TRÀN - is a researcher at Southern Institute of Ecology and Becamex Institute of Research and Development and have experience in most of the forests in Southern Vietnam and few in Northern Vietnam. His conducted research on taxonomy, including characterization of Sapria himalayana morphology identification. He and his team acquired the samples in this study.

Syarifah Haniera Sheikh KAMAL - is postgraduate student (MSc) with a special interest in plant anatomy and conservation. She carried out the anatomical study on Rafflesia species with the host, Tetrastigma and morphology, growth and mortality rate of Rafflesia species.

\section{Acknowledgements}

This work is partially funded by Lam Dong Provincial Department of Natural Resource and Environment through contract number 09/HDDV dated 12 April 2021. We thank Nguyễn Thị Ngọc Hương (Ho Chi Minh City Medicine and Pharmacy University, Faculty of Pharmacy) for preparing the microscope sampling.

\section{References}

AHMAD A., KUMAR A., RAWAT G. S. \& GOPI G. V. 2020. Recent record of a threatened holoparasitic plant Sapria Himalayana Griff. in Mehao Wildlife Sanctuary, Arunachal Pradesh, India. Journal of Threatened Taxa. 12(10): 16399-16401. https://doi.org/10.11609/jott.5168.12.10.16399-16401

BÄNZIGER H. \& HANSEN B. 1997. Unmasking the real identity of Sapria poilanei Gagnepain emend. and description of Sapria ram sp. n. (Rafflesiaceae). Natural History Bulletin of the Siam Society. 45: 149-170.

BASCOS E. M. A., FERNANDO E. S., DUYA M. V., RODRIGUEZ L. J. V. 2021. Beginnings of a plant parasite: early development of Rafflesia consueloae inside its Tetrastigma host. Planta. 254: 61. https://doi.org/10.1007/s00425-021-03710-4

BECK C. B. 2010. An introduction to plant structure and development. $2^{\text {nd }}$ ed. Cambridge Press, Cambridge, UK: $306-$ 308.

CHAMCHUMROON V., NANTHAWAN S., TETSANA N., POOPATH M. \& TANIKKOOL S. 2017. Threatened Plants in Thailand. Office of the Forest Herbarium, Forest and Plant Conservation Research Office, Department of National Park, Wildlife and Plant Conservation Ministry of Natural Resources and Environment, Bangkok, Thailand: 223.

ELLIOTT S. 1992. Status, ecology and conservation of Sapria himalayana Griff. (Rafflesiaceae) in Thailand. Warasan Satpa Muang Thai. 2(1): 44-52.

GAMBETTA G. A., FEI J., ROST T. L., KNIPFER T., MATTHEWS M. A., SHACKEL K. A., WALKER M. A. \& MCELRONE M. J. 2013. Water uptake along the length of grapevine fine roots: developmental anatomy, tissue-specific, aquaporin expression, and pathways of water transport. Plant Physiology. 163: 1254-1265. https://doi.org/10.1104/pp.113.221283

HUANG S. \& GILBERT M. G. 2003. Rafflesiaceae Dumortier. In: WU, Z. Y., RAVEN P. H. \& HONG D. Y., eds. 2003. Flora of China. Vol. 5 (Ulmaceae through Basellaceae). Science Press, Beijing, and Missouri Botanical Garden Press, St. Louis: 270-271.

KAMAL S. H. S., SURATMAN M. N., KHAMIS S., HASSAN A. N. \& MOHAMMAD M. S. 2021. Host-parasitic relationships between Tetrastigma rafflesiae and Rafflesia azlanii and Rafflesia cantleyii in BelumTemenggor Forest Complex, Perak, Malaysia. Pertanika Journal of Tropical Agricultural Science. 44: 755771. https://doi.org/10.47836/pjtas.44.4.04

LOCQUIN M. \& LANGERON M. 2013. Handbook of Microscopy. Butterworth-Heinemann Books, Oxford, UK: 228 pp.

MURSIDAWATI S., WICAKSONO A. \& TEIXEIRA DA SILVA J. A. 2019. Development of the endophytic parasite, Rafflesia patma Blume, among host plant (Tetrastigma leucostaphylum (Dennst.) Alston) vascular cambium tissue. South African Journal of Botany. 123: 382-386. https://doi.org/10.1016/j.sajb.2019.03.028 
MURSIDAWATI S. \& WICAKSONO A. 2020. Tissue differentiation of the early and the late flower buds of Rafflesia patma Blume. Journal of Plant Development. 27: 19-32. https://doi.org/10.33628/jpd.2020.27.1.19

MURSIDAWATI S., WICAKSONO A. \& TEIXEIRA DA SILVA J. A. 2021. Tetrastigma leucostaphylum (Dennst.) Alston ex Mabb. partial wedge sampling, a new, less-invasive solution for stem-borne versus root-borne Rafflesia identification. Philippine Journal of Science. 150(5): 1141-1152.

NAIS J. 2001. Rafflesia of the World. Sabah Parks Borneo, Malaysia: 119-191.

NANTAWAN S. \& SUVIT S. 2002. Morphology and anatomy of bua pud (Rafflesia kerrii Meijer) in Thailand. Thailand Journal of Forestry. 19-21: 146-165.

NIKOLOV L. A., TOMLINSON P. B., MANICKAM S., ENDRESS P. K., KRAMER E. M. \& DAVIS C. C. 2014 a. Holoparasitic Rafflesiaceae possess the most reduced endophytes and yet give rise to the world's largest flowers. Annals of Botany. 114(2): 233-242. https://doi.org/10.1093/aob/mcu114

NIKOLOV L. A., STAEDLER Y. M., MANICKAM S., SCHÖNENBERGER J., ENDRESS P. K., KRAMER E. M., \& DAVIS C. C. 2014b. Floral structure and development in Rafflesiaceae with emphasis on their exceptional gynoecia. American Journal of Botany. 101(2): 225-243. https://doi.org/10.3732/ajb.1400009

RAHAYU C., CHIKAMAWATI T. \& WIDJAJA E. A. 2018. Nomenclatural study of Tetrastigma leucostaphylum and Tetrastigma rafflesiae (Vitaceae): two common hosts of Rafflesia in Sumatra. Reinwardtia. 17(1): 59-66. http://doi.org/10.14203/reinwardtia.v17i1.3552

SUSATYA A. 2020. The growth of flower bud, life history, and population structure of Rafflesia arnoldii (Rafflesiaceae) in Bengkulu, Sumatra, Indonesia. Biodiversitas Journal of Biological Diversity. 21(2): 792798. https://doi.org/10.13057/biodiv/d210247

TRẦN H. Đ., LUUU H. T., NGUYẼ̃N Q. Đ., NGUYẼ̃N H. C., ATHEN P. \& WONG K. M. 2018. Identification, sexual dimorphism and aspects of the natural history of Sapria himalayana (Rafflesiaceae) on Vietnam's Lang Biang Plateau. Botanical Studies. 59(1): 1-10.

WEAVER S. 2015. Origin of symbiosis in Rafflesiaceae: insights from molecular dating of horizontally transferred genes from host to parasite (Doctoral dissertation, Long Island University, The Brooklyn Center).

WICAKSONO A., MURSIDAWATI S. \& MOLINA J. 2020. A plant within a plant: insights on the development of the Rafflesia endophyte within its host. The Botanical Review. 87(2): 233-242.

\section{How to cite this article:}

WICAKSONO A., TRẦN H. Đ. \& KAMAL S. H. S. 2021. Preliminary histoanatomical study of Sapria himalayana Griff. f. albovinosa flower buds and its intersection with its host plant Tetrastigma laoticum Gagnep. J. Plant Develop. 28: 23-31. https://doi.org/10.47743/jpd.2021.28.1.888 